\title{
Formulation and physical evaluation of facial cream preparations from Ceremai fruit juice (Phyllanthus acidus (I.) Skeels)
}

\author{
Danang Indriatmoko ${ }^{1}$, Nani Suryani ${ }^{2}$, Tarso Rudiana ${ }^{2}$, Mila Kurniah ${ }^{1}$ \\ ${ }^{1}$ Pharmacy Study Program, Mathla'ul Anwar University, Banten, Indonesia \\ ${ }^{2}$ Chemistry Study Program, Mathla'ul Anwar University, Banten, Indonesia
}

\author{
Keywords \\ AHA \\ Cream \\ Freeze-drying \\ Phyllanthus acidus $\mathrm{L}$.
}

\section{Correspondence}

Dimas Danang Indriatmoko

Pharmacy Study Program

Mathla'ul Anwar University

Banten

Indonesia

dimasdanangindriatmoko@gmail.com

\begin{abstract}
Introduction: Ceremai (Phyllanthus acidus (L.) Skeels) fruit contains AHA (Alpha Hydroxy Acids) compounds which are widely used as a moisturizer or as an exfoliating process in cosmetics production. It also contains vitamin $\mathrm{C}$ and flavonoids, both of which acts as whitening agents. Aim: This study aims to utilise a source of natural AHA active substances found in P.acidus in face cream preparations. Methods: The juice from P.acidus was dried by freeze-drying method and formulated into a cream with the preparation process evaluated for one month. Results: The observation results showed that after one month, there was no change in colour during storage, with the $\mathrm{pH}$, viscosity and spreadability of the cream in the range 4.5-6.2, 2700-3996 cps, and 4.8-5.7 cm, respectively. Conclusion: P.acidus fruit juice containing AHA can be formulated into a face cream with good physical stability.
\end{abstract}

\section{Introduction}

Indonesia is one of the countries that lie along the equator; therefore, its climate is entirely tropical, which means that people are exposed to solar radiation every year compared to other countries not crossed by the equator. On the surface of the earth, sunlight consists of various spectra, including infrared light (> $760 \mathrm{~nm}$ ), visible light (400-760 $\mathrm{nm}$ ), ultraviolet light (UV) A rays (315-400 $\mathrm{nm})$, UV B rays (290-315 $\mathrm{nm}$ ) and UV C rays (100-290 nm). According to Agustin and the authors (2013), moderate amounts of radiation can provide a sense of comfort and health for the human body, while continuous exposure to high-intensity sunlight tends to interfere with skin health, thereby leading to changes in connective tissue, capable of causing premature ageing, skin cancer, hyperpigmentation, as well as black and scaly skin. In addition to continuous sun exposure, changes in facial skin colour can also be caused by lack of sleep, fatigue, dust and air pollution. To some people, the change in skin colour from fair to black is a very sensitive matter because it relates to appearance. Therefore, one of the techniques used to overcome dull skin and whitening facial skin is by using a face cream containing AHA (Alpha Hydroxy Acid), which is a carboxylic and hydrophilic acid group. AHAs are also known as fruit acids because they are commonly found in fruit, for example, citric, malic and tartaric acids in citrus fruits, apples, and grapes. AHAs which are not components of the fruit include glycolic acid from sugar cane and lactic acid from milk. It is also used as a moisturizer and exfoliates the skin from the top layer of the stratum corneum to the lowest through a keratolytic process (Tang \& Yang, 2018). 
Ceremai (Phyllanthus acidus (L.) Skeels) originated from India and belonged to the Euphorbiaceae family. This tree grows in light to heavy soils and is resistant to deficient or excess water. The roots contain saponins, tannins and toxic substances. The leaves, bark, stems, and wood comprises saponins, flavonoids, tannins and polyphenols, while the fruit contains vitamin C (Andrianto et al., 2017). Selpiana and the authors (2015) stated that the most commonly used parts of this tree are the roots, leaves and seeds, with the fruit widely used as sweets and food flavouring due to its sour taste. Therefore, it is necessary to carry out research on $P$. acidus fruit as medicine. Previous studies on $P$. acidus fruit led to several findings regarding its use as medicine, such as as an antipyretic, antidiarrhoea, and analgesic (Afrin et al., 2015) hepatoprotective (Jain et al., 2010), and antioxidants (Andrianto et al., 2017).

$P$. acidus fruit contains vitamin $\mathrm{C}$ and flavonoids (Andrianto et al., 2017). According to Hanani (2017), flavonoids are the largest phenol group found in plants and comprise two or more hydroxyl groups with antioxidant activities that are good for the skin. Phenol is an alcohol compound, which reacts with strong acid oxidizing agents to form carboxylic acids. Meanwhile, vitamin C has the role of changing the paler melanin in the reduced form and prevents its formation by inhibiting dopa quinones, thereby brightening normal and pigmented skin (Kembun et al., 2012).

The water content contained in $P$. acidus fruit is 91.7 grams / 100 grams (Selpiana et al., 2015); therefore, this study used a sampling method from fruit juice. In addition, AHA compounds are soluble with high antioxidant content using a water solvent containing an $\mathrm{LC}_{50}$ value of $26.06 \mu \mathrm{g} / \mathrm{mL}$ (Andrianto et al., 2017).

This study aims to utilise a source of natural AHA active substances found in P.acidus fruit. The research included plant determination, making fruit juice samples using the freeze-drying method. The advantages of the freeze-drying method include maintaining sample stability, maintaining the stability of the material structure and increasing rehydration power (January \& Martin, 2014). Phytochemical screening was carried out by testing flavonoids, alkaloids, steroids and terpenoids, saponins and tannins. The cream formulation uses excipient stearic acid, TEA (Triethanolamine), methylparaben, propylparaben, Oleum Cocos, glycerin, cetyl alcohol, and Oleum Rosae. Then performed a physical evaluation of the preparation, which includes organoleptic observation, $\mathrm{pH}$ measurement, spreadability test, viscosity test.

\section{Methods \\ P. acidus fruit determination}

Plant determination aims to examine the morphology of P.acidus plants, such as the colour, smell and taste through organoleptic tests and to use the Indonesian Institute of Sciences (LIPI), Bogor Herbarium.

\section{Freeze-dried P. acidus fruit juice preparation}

The manufacture of $P$. acidus fruit juice begins with wet sorting of $P$. acidus fruit; the goal is to separate impurities or other foreign materials from Simplicia. This step was followed by washing to remove impurities attached to the simplicia and the separation of the pulp from the seeds. The pulp that has been separated from the seeds is mashed, then squeezed using a filter to separate the filtrate from the residue. The juice that has been separated is then dehydrated using freezedrying at a temperature of $-5^{\circ} \mathrm{C}$ for 24 hours (January \& Martin, 2014).

\section{Phytochemical screening (Sangi et al., 2018)}

Phytochemical screening is carried out by determining the flavonoid, alkaloid, steroid and terpenoid, saponin, and tannin content.

\section{Flavonoid test}

Approximately $2 \mathrm{~mL}$ of $P$.acidus juice was pipette, put into a test tube and heated before ethanol was added. Magnesium and Hydrochloric acid $(\mathrm{HCl} 2 \mathrm{~N}$ tape are added to the solution, and the formation of a red solution indicates the presence of flavonoids.

\section{Alkaloid test}

A total of $2 \mathrm{~mL}$ of $P$.acidus juice was put into a test tube, dissolved with $5 \mathrm{~mL}$ of chloroform and three drops of ammonia, with the addition of two drops of concentrated $\mathrm{H}_{2} \mathrm{SO}_{4}$ and divided into two test tubes. The first tube is added with three drops of Wagner's reagent, positive for alkaloids, assuming a brown precipitate is formed. The second tube is added with three drops of Mayer reagent and found to be positive for alkaloids assuming a white to yellowish precipitate is formed.

\section{Steroid and terpenoid test}

A total of $2 \mathrm{~mL}$ of $P$.acidus fruit juice was put into a test tube and dissolved in $0.5 \mathrm{~mL}$ of chloroform. Furthermore, $0.5 \mathrm{~mL}$ of anhydrous acetic acid was added with $2 \mathrm{~mL}$ of concentrated sulfuric acid dropped in the mixture through the test tube wall. The formation of a bluish-green colour indicates the 
presence of steroids, while brown or violet rings indicate a terpenoid.

\section{Saponin test}

A total of $2 \mathrm{~mL}$ of P.acidus fruit juice was put into a test tube and added with $10 \mathrm{~mL}$ of hot water-cooled and shaken vigorously for 10 seconds. The inability of the foam to disappear after adding $\mathrm{HCl} 2 \mathrm{~N}$ indicates the presence of saponin.

\section{Tannin test}

A total of $2 \mathrm{~mL}$ of P.acidus fruit juice was put into a test tube, and $1 \mathrm{~mL}$ of $10 \%$ ferric (III) chloride solution was added; the formation of a dark blue/greenish-black colour indicates the presence of tannins.

\section{Cream formulation and manufacturing process}

The formula for P.acidus fruit cream is shown in Table I.

Table I: P.acidus fruit cream formula

\begin{tabular}{lll}
\hline \multicolumn{1}{c}{ Ingredient } & Amount & \multicolumn{1}{c}{ Function } \\
\hline $\begin{array}{l}\text { - P.acidus L. fruit } \\
\text { freeze drying } \\
\text { extract }\end{array}$ & $\bullet 6,76 \mathrm{~g}$ & - Active ingredient \\
- Stearic acid & & \\
- TEA & - $5,5 \mathrm{~g}$ & - Emulsifying agent \\
- Methylparaben & - $1,5 \mathrm{~mL}$ & - Emulsifying agent \\
- Propylparaben & - $0,3 \mathrm{~g}$ & - Preservative \\
- Oleum Cocos & - $2,2 \mathrm{~g}$ & - Preservative \\
- Glycerin & - $1,8 \mathrm{~mL}$ & - Emulsifying agent \\
- Cetyl alcohol & - $2 \mathrm{~g}$ & - Thickening agent \\
- Oleum Rosae & - $2 \mathrm{drops}$ & - Corrigen Odours \\
- Aquadest & ad $100 \mathrm{~mL}$ & - Solvent \\
\hline
\end{tabular}

The manufacturing process is done by mixing cetyl alcohol, stearic acid, propylparaben and Oleum Cocos, then heating it to melt and stirring until it is homogeneous (oil phase). Mixed with TEA, glycerin, methylparaben and add $30 \mathrm{~mL}$ of aqua dest until homogeneous (water phase). Mix the oil phase into the water phase until the mixture thickens and cools. Put the P.acidus fruit freeze drying extract that has been dissolved first with $40 \mathrm{~mL}$ aqua dest into the mixture. Add two drops of Oleum Rosae and the remaining distilled water, stir until homogeneous.

\section{Evaluation of preparations}

Organoleptic observation

Organoleptic observations were carried out by examining the colour, smell, shape and texture of the preparation.

\section{pH measurement}

$\mathrm{pH}$ measurement is carried out by dissolving the cream in water with a ratio of $1: 3$, stirring until homogeneous and allowed to stand until it settles. The water is drawn and measured using a $\mathrm{pH}$ meter with the requirement for a good cream between $4.5-6.5$.

\section{Spreadability test}

The formulated cream is carefully placed on the paper that is overlapped with transparent glass and left for a while. The area given by the preparation is calculated, and the cream is recovered with a glass that has a load equal to the amount of weight of each glass used and overwritten with a load of 50, $100 \& 150$ grams. Each load is left for 60 seconds because the wider the diameter, the better the spread.

\section{Viscosity test}

The cream was put into a cup glass container with its viscosity measured using an NDJ $5 S$ viscometer before it is read and recorded. Furthermore, a cream is said to meet the viscosity requirements when it is in the range of 2000-50000 cps.

\section{Results}

$P$. acidus fruit was determined based on a letter from the Indonesian Institute of Sciences with a letter number B-1216/IPH.3/KS/X/2020, which explained that the sample used in the study was Phyllanthus acidus (L.) Skeels from the Phyllanthaceae family.

Phytochemical screening was used to determine the active substance content of P.acidus fruit is shown in Table II. The results of the phytochemical screening of $P$. acidus fruits showed that $P$. acidus fruit positively contained flavonoids, alkaloids, terpenoids, saponins, tannins and did not contain steroids.

Table II: Phytochemical screening results of P.acidus L. fruit

\begin{tabular}{ll}
\hline Secondary Metabolites & Result \\
\hline Flavonoid & Positive \\
Alkaloid & Positive \\
Steroid & Negative \\
Terpenoid & Positive \\
Saponin & Positive \\
Tannin & Positive \\
\hline
\end{tabular}

\section{Formulation and evaluation of preparations}

The organoleptic test results showed that the cream base was white, while the P.acidus fruit cream sample 
was brownish in colour. Base and sample rose-scented, semi-solid shape and texture; these characteristics were stable for five weeks. The results of organoleptic observations are shown in Table III.

Table III: Organoleptic test results of $P$.acidus fruit cream

\begin{tabular}{|c|c|c|c|}
\hline Test Parameters & Time & Sample & Basis \\
\hline \multirow[t]{4}{*}{ Colour } & Week 0 & Brown & White \\
\hline & Week 1 & Brown & White \\
\hline & Week 4 & Brown & White \\
\hline & Week 5 & Brown & White \\
\hline \multirow[t]{4}{*}{ Smell } & Week 0 & Rose & Rose \\
\hline & Week 1 & Rose & Rose \\
\hline & Week 4 & Rose & Rose \\
\hline & Week 5 & Rose & Rose \\
\hline \multirow[t]{4}{*}{ Shape } & Week 0 & Semi-solid & Semi-solid \\
\hline & Week 1 & Semi-solid & Semi-solid \\
\hline & Week 4 & Semi-solid & Semi-solid \\
\hline & Week 5 & Semi-solid & Semi-solid \\
\hline \multirow{4}{*}{$\begin{array}{l}\text { Texture of the } \\
\text { preparation }\end{array}$} & Week 0 & Semi-solid & Semi-solid \\
\hline & Week 1 & Semi-solid & Semi-solid \\
\hline & Week 4 & Semi-solid & Semi-solid \\
\hline & Week 5 & Semi-solid & Semi-solid \\
\hline
\end{tabular}

The results of testing the $\mathrm{pH}$ of the cream samples showed that the $\mathrm{pH}$ tends to increase, namely at the beginning of manufacture, it was 4.5 , after a week of storage, it was 4.6 , after four weeks of storage, it was 4.8 , and after five weeks of storage was 6.2. The $\mathrm{pH}$ test carried out for five weeks are shown in Figure 1.

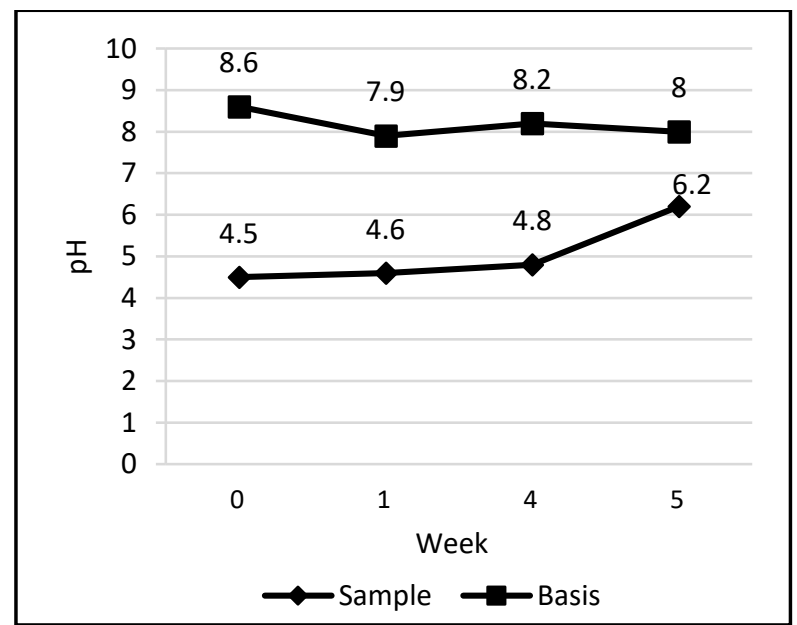

Figure 1: pH test chart

The results of the spreadability test of cream preparations showed that the spreadability of the cream samples was quite stable, namely, at the beginning of manufacture, it had a spreading power of
$5.6 \mathrm{~cm}$, after a week of storage, it was $5.4 \mathrm{~cm}$, after four weeks of storage was $5.2 \mathrm{~cm}$, and after five weeks of storage was $5.2 \mathrm{~cm}$. The spreadability of the cream was carried out using two tests, namely the sample and the cream base, as shown in Figure 2.

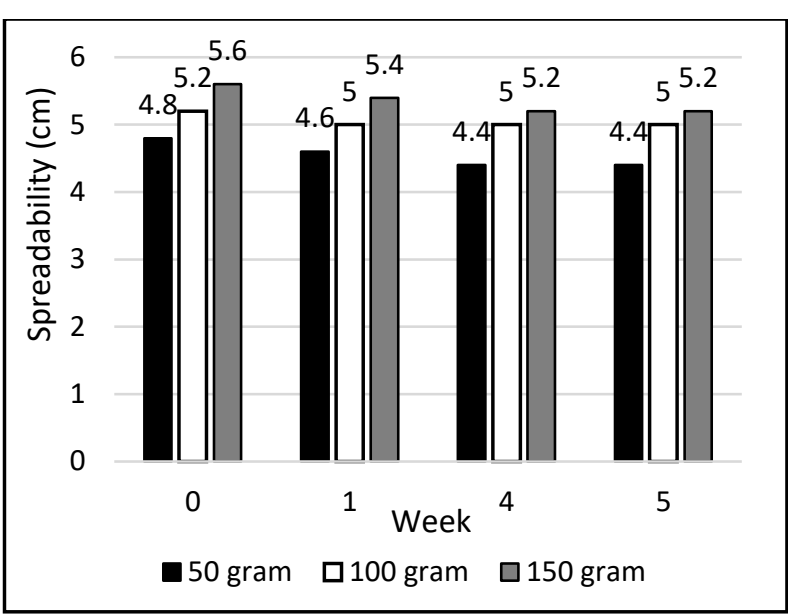

Figure 2: Spreadability test result chart

The viscosity test on the sample cream showed that the cream had a good viscosity, namely 2700 to 3996 cps for five weeks of storage. The viscosity test was carried out using a viscometer, as shown in Table IV.

Table IV: Viscosity data

\begin{tabular}{llc}
\hline Week & Test material & Viscosity \\
\hline 0 & Sample & 2700 \\
& Basis & 2304 \\
\multirow{2}{*}{1} & Sample & 3287 \\
& Basis & 3996 \\
4 & Sample & 3996 \\
\multirow{2}{*}{5} & Basis & 3996 \\
& Sample & 3996 \\
& Basis & 3996 \\
\hline
\end{tabular}

\section{Discussion}

Determination is a stage carried out in a study with the aim and purpose of knowing the truth regarding the identity of plants. The determination of P.acidus plants used as samples in this study was carried out at the Indonesian Institute of Sciences (Lembaga IImu Pengetahuan Indonesia (LIPI)). The results indicated that the sample used was a type of Phyllanthus acidus (L.) Skeels from the Phyllanthaceae family. 
After the wet sorting and washing processes, the pulp and seeds were separated. The separated pulp is further blended to get a smaller particle size to obtain a larger sample surface area with the solvent. The greater contact with the solvent makes it easier for the solvent to attract the compounds contained in a sample.

The extraction method used to extract the active substance from P.acidus fruit is the squeeze method using a blender because the test material is not heatresistant, and this method does not require a prolonged process (Rusdiaman, 2018). The fruit juice that has been separated is then dried using the freeze-drying process. The product advantages due to freeze-drying include maintaining stability, material structure, and increasing rehydration power (January \& Martin, 2014).

The phytochemical test is used to analyse the content of secondary metabolites found in plants, with many benefits, such as protection from predators and parasites. Apart from being used by the plants themselves, secondary metabolites can also be used as medicine.

The data from the observation of the qualitative phytochemical test of $P$. acidus with parameters of the active phytochemical compounds, including flavonoids, steroids, terpenoids, alkaloids, saponins and tannins, are shown in Table II. The observations show that P.acidus fruit contains secondary metabolites that function as medicinal agents. Secondary metabolite compounds contained in P.acidus fruit include saponins, terpenoids, flavonoids and alkaloids. The reaction that occurs between the sample and the reagent leads to a change in colour and the formation of sediment (Habibi et al., 2018). The flavonoid test shows positive results due to the formation of a red colour after the addition of $\mathrm{Mg}$ and $\mathrm{HCl}$, which reacts to form $\mathrm{H}_{2}$ gas bubbles, while the concentrated $\mathrm{Mg}$ and $\mathrm{HCl}$ metals in this test function to reduce the benzopyrone core contained in the flavonoid structure, thereby forming a red or orange colour. According to Nuryanti and the authors (2016), the presence of flavonoid compounds in a plant extract forms red or orange salts with the addition of $\mathrm{Mg}$ and $\mathrm{HCl}$.

Furthermore, the alkaloid test showed positive results with the formation of sediment after adding Mayer and Wagner reagents. A positive result of alkaloids in the Mayer test is indicated by the formation of a yellowishwhite precipitate, which is a potassium alkaloid complex. Meanwhile, the addition of Wagner's reagent forms a brown precipitate caused by iodine reacting with ion $\mathrm{I}^{-}$ from potassium iodide to produce brown ion $I_{3}^{-}$. In the Wagner test, $\mathrm{K}^{+}$metal ions form coordinate covalent bonds with nitrogen in the alkaloids, thereby leading to the formation of a precipitated alkaloid potassium complex, which indicates a positive alkaloid result. The saponin test produces positive results with the formation of foam after adding hot water (Adhariani et al., 2018).

Steroid and terpenoid tests showed positive results with the formation of a violet colour change and negative for steroid tests after the addition of Lieberman Burchard reagent. The colour change after the addition of Lieberman Burchard's reagent was based on the formation of terpenoid compounds by $\mathrm{H}_{2} \mathrm{SO}_{4}$ in an anhydrous acetic acid solvent. The obtained colour difference is due to variation in groups on the C-4 atom (Marliana \& Saleh, 2011).

The tannin test produced a positive result with the formation of a dark blue/black colour, which changed after the addition of $\mathrm{FeCl}_{3}$ because tannins form complex compounds with $\mathrm{Fe}^{3+}$ ions (Ergina et al., 2014).

Evaluation of the properties of cream preparations aims to determine the stability of the preparation stored at room temperature, which includes evaluation of organoleptic, $\mathrm{pH}$, spreadability and viscosity.

The organoleptic test aims to determine the colour, smell, shape and texture of the cream preparation, with the test results indicating that the base was white while the P.acidus fruit cream was brownish in colour due to the addition of P.acidus fruit extract. The observations made from week zero to four remained stable, with brown colour.

The $\mathrm{pH}$ test for cream preparations is used to determine the suitability of the degree of acidity of the cream formulas to ensure they can be applied to the skin. $\mathrm{pH}$ measurement using the Hanna $\mathrm{HI} 2211 \mathrm{pH}$ meter was based on the National Agency of Drug and Food Control (BPOM) regulations regarding the classification of cosmetics containing AHA for group one with its content up to $10 \%$ using a $\mathrm{pH}$ range of 3.5 and above (Badan Pengawas Obat dan Makanan, 2006). In the $\mathrm{pH}$ test results, P.acidus fruit cream met the requirement because it was in the range of 4.6 to 6.2 . In testing the $\mathrm{pH}$ of the cream, results that tend to increase were due to the possibility of an oxidation reaction of $-\mathrm{OH}$ molecules contained in citric and glycolic acid compounds found in P.acidus fruit cream. Meanwhile, based on the cream, the $\mathrm{pH}$ range between 8.6-8.0 tends to be alkaline due to the small amount of triethanolamine and stearic acid contained in cream preparations.

The viscosity test was carried out to determine the thickness of the cream preparation, which is the resistance of a preparation to flow; therefore, the greater the resistance, the higher the possibility of the viscosity to affect its distribution. The cream's viscosity was measured using the NDJ 55 viscometer, which obtained 2700 to $3996 \mathrm{cps}$ in accordance with the requirements of a good cream (2000-50000 cps), while 
the base was almost similar to the sample. In measuring the viscosity from week zero, there was an increase in viscosity from 2700 to $3996 \mathrm{cps}$, due to the rise in the proportion of the dispersed phase. Furthermore, an increase in the concentration of the emulsifier decreased the particle size. The greater the resistance, the greater the viscosity. Elcistia \& Zulkarnaen (2018) stated that creams with high viscosity are difficult to pour into a container, while those that are too low are thin and tend to easily drip when applied to the skin.

The spreadability test of the cream aims to determine its ability to stick to the skin surface when used. The longer the stickiness of the cream to the skin, the more active the substances absorbed. Mukhlishah and authors (2016) stated that the dispersibility requirements for topical preparations are $5-7 \mathrm{~cm}$. The results of the spreadability test for cream preparations showed that the results increased every week and met the requirements for good topical preparations.

\section{Conclusion}

P.acidus fruit juice containing AHA can be formulated into a face cream with good physical stability. The stability of the cream preparations from P.acidus fruit was good stability and in accordance with the standard requirements. The cream has a $\mathrm{pH}$, viscosity and spreadability in the range of 4.6-6.2, 2700-3996 cps, and $5.2-5.6 \mathrm{~cm}$, respectively.

\section{Acknowledgements}

The authors are grateful to the Ministry of Research and Technology/National Research and Innovation Agency (Kementerian Riset dan Teknologi/Badan Riset dan Inovasi Nasional) for the research funding assistance through the Beginner Lecturer Research (Penelitian Dosen Pemula) for the 2020 fiscal year.

\section{References}

Adhariani, M., Maslahat, M., \& Sutamihardja, R.T.M. (2018). Kandungan fitokimia dan senyawa kation pada daun khat merah (Catha edulis). Sains Natural, 8(1), 35-42. https://doi.org/10.31938/jsn.v8i1.113

Afrin, F., Banik, S., \& Hossain, M.S. (2015). Pharmalogical activities of methanol extract Phyllantus acidus Pulp. Jounal of Medicinal Plants Research, 10(43), 790-795. https://doi.org/10.5897/JMPR2015.5806

Agustin, R., Oktadefitri, Y., \& Lucida, H. (2013). Formulasi krim tabir surya dari kombinasi etil p-metoksinamat dengan katekin. Prosiding Seminar Nasional Perkembangan Terkini Farmasi dan Klinik III ISSN : 184-198

Andrianto, D., Widianti, W., \& Bintang, M. (2017). Antioxidant and cytotoxic activity of Phyllanthus acidus fruit extracts. IOP Conference
Series: Earth and Environmental Science, 58. Available at:https://iopscience.iop.org/article/10.1088/17551315/58/1/012022

Badan Pengawas Obat dan Makanan. (2006). Petunjuk teknis pengawasan alpha hydroxy acid (aha) dalam kosmetik. Badan Pengawas Obat dan Makanan. Available at: https://jdihn.go.id/search/pusat/detail/585824

Elcistia, R., \& Zulkarnaen, A.K. (2018). Optimasi formula sediaan krim o/w kombinasi oksibenzoil dan titanium dioksida serta uji aktivitas tabir suryanya secara in vivo. Majalah Farmaseutik, 14(2), 63-78. Available

https://jurnal.ugm.ac.id/majalahfarmaseutik/article/download/425 $96 / 23520$

Ergina, Nuryanti, S., \& Pursitasari, I.D. (2014). Uji kualitatif senyawa metabolit sekunder pada daun palado (Agave agustifolia) yang di ekstraksi dengan pelarut air dan etanol. Jurnal Akademika Kimia, 3(3), 165-172. Available at: http://jurnal.untad.ac.id/jurnal/index.php/JAK/article/view/7797

Habibi, A.I., Firmansyah, R.A., \& Setyawati, S.M. (2018). Skrining fitokimia ekstrak n-heksan korteks batang salam (Syzygium polyanthum). Indonesian Journal of Chemical Science, 7(1), 1-4. Availableat: https://journal.unnes.ac.id/sju/index.php/ijcs/article/view/23370

Hanani E. (2014). Analisis Fitokimia. Jakarta: Penerbit Buku Kedokteran EGC

Jain, N.K. \& Singhai, A.K. (2011). Protective effects of Phyllanthus acidus (L.) Skeels leaf extracts on acetaminophen and thioacetamide induced hepatic injuries in Wistar rats. Asian Pacific Journal of Tropical Medicine, 4(6), 470-474. https://doi.org/10.1016/S19957645(11)60128-4

Kembun, M.V., Wangko, S., \& Tanudjaja G.N. (2012). Peranan vitamin c terhadap pigmentasi kulit. Jurnal Biomedik, 4(3), S13-17. Available at: https://ejournal.unsrat.ac.id/index.php/biomedik/article/download/1215/992

Marliana, E., \& Saleh, C. (2011). Uji fitokimia dan aktivitas antibakteri ekstrak kasar etanol fraksi n-heksana, etil asetat dan metanol dari buah labu air (Lagenari siceraria (Molina) Standl). Jurnal Kimia Mulawarman, 8(2), 39-63. Available at: http://jurnal.kimia.fmipa.unmul.ac.id/index.php/JKM/article/view/6 03

Mukhlishah, N.R.I., Sugihartini, N., \& Yuwono, T. (2016). Daya iritasi dan sifat fisik sediaan salep minyak atsiribunga cengkeh

(Syzigium aromaticum) pada basis hidrokarbon. Majalah Farmaseutik, 12(1), 372-376. Available at: https://jurnal.ugm.ac.id/majalahfarmaseutik/article/download/241 $30 / 15786$

Nuryanti, S., Mustapa, K., \& Sudarmo I.G. (2016). Uji daya hambat ekstrak buah kelor (Moringa oleifera Lamk) terhadap pertumbuhan jamur Candida albicans. Jurnal Akademika Kimia, 5(4), 178-184.

http://jurnal.untad.ac.id/jurnal/index.php/JAK/article/view/8067

Rusdiaman. (2018). Uji daya hambat perasan buah belimbing wuluh (Averrhoa bilimbi L.) terhadap pertumbuhan Propionibacterium

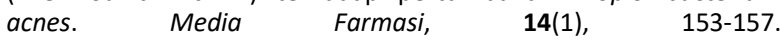
https://doi.org/10.32382/mf.v14i1.150

Sangi, M., Runtuwene, M.R.J., Simbala, H.E.I., \& Makang, V.M.A. (2008). Analisis fitokimia tumbuhan obat di Kabupaten Minahasa Utara. Chemistry Progress, 1(1), 47-53. https://doi.org/10.35799/cp.1.1.2008.26

Selpiana, Ulfa, A. \& Maryam, M. (2015). Pemanfaatan sari buah ceremai (Phyllanthus acidus) sebagai alternatif koagulans lateks. Jurnal Teknik Kimia, 1 (21), 29-36. Available at: http://ejournal.ft.unsri.ac.id/index.php/jtk/article/view/102

Tang S.C. \& Yang J.H. (2018). Dual effect of alpha hydroxy acids on the skin. Molecules, 23 (4): 863. https://doi.org/10.3390/molecules23040863 